\title{
Tortuous internal carotid artery: an important differential of the pulsatile oropharyngeal mass
}

\author{
Michelle Pipe (D) ,' Emma Watts (D) ,' Peter George Deutsch, ${ }^{3}$ \\ Giridharan Wijayasingam ${ }^{4}$
}

${ }^{1}$ University Hospitals Birmingham NHS Foundation Trust, Birmingham, UK ${ }^{2}$ ENT, University Hospitals Birmingham NHS Foundation Trust, Birmingham, UK ${ }^{3}$ Otolaryngology, Sandwell and West Birmingham Hospitals NHS Trust, Birmingham, UK ${ }^{4}$ ENT, Russells Hall Hospital, Dudley, UK

\section{Correspondence to}

Dr Michelle Pipe;

michelle.41@hotmail.co.uk

Accepted 3 September 2020

\section{DESCRIPTION}

A 69-year-old woman presented to her local head and neck clinic with a 6-month history of rightsided sore throat and intermittent dysphagia, with a normal voice. On examination, a longitudinal, pulsatile lesion in the right posterolateral pharyngeal wall commenced at the junction of the oropharynx and nasopharynx, and progressed to the vallecular. Flexible nasendoscopy was otherwise normal. Her medical history included asthma, gastro-oesophageal reflux, hypertension and tonsillectomy. She is a non-smoker and occasionally drinks alcohol. She is a retired intensive care senior sister.

CT angiogram showed a tortuous right internal carotid artery (ICA) which looped medially at the level of the oropharynx, bulging into the right pharyngeal wall before returning laterally to enter the carotid canal in its normal anatomical position (figures 1 and 2). Imaging revealed normal aortic arch, no further aneurysm of vascular anomaly and the left carotid artery was completely normal.

An aberrant cervical ICA with relation to the pharyngeal wall ${ }^{12}$ is thought to affect between $0.2 \%$ and $2 \%$ of the population. The majority are asymptomatic ${ }^{3}$; this patient unusually presented with intermittent dysphagia and sore throat. It is thought that this patient's symptom of dysphagia is secondary to a globus sensation within the oropharynx, given the sensitivity of the anatomical region. Other cases report symptoms of pulsatile mass, hoarseness, pain, obstructive throat sensation $^{24}$ and less commonly dysphagia ${ }^{56}$; mild cough, globus sensation and aspiration ${ }^{5}$ may also occur. Rarely, patients may present with temporary blindness, objective tinnitus, ${ }^{67}$ pharyngitis ${ }^{8}$ or neck mass. ${ }^{8}$

A tortuous ICA is an important differential diagnosis in suspected peritonsillar abscess and parapharyngeal neoplasm due to the necessity for fine needle aspiration or biopsy and the associated risk of major haemorrhage. While uncommon, awareness of this anatomical abnormality is essential in preventing morbidity and mortality. Some cases report alterations in the ICA found during surgical procedures and careful adaptations which have subsequently been made during the surgery. ${ }^{6}$ In one case, an ICA was detected $1 \mathrm{~cm}$ to the left of the tonsils during tonsillectomy; this highlights the tangible risks to these patients. ${ }^{6}$ Further, research shows tortuosity of the ICA as a risk factor for cerebral ischaemic stroke. ${ }^{9}$

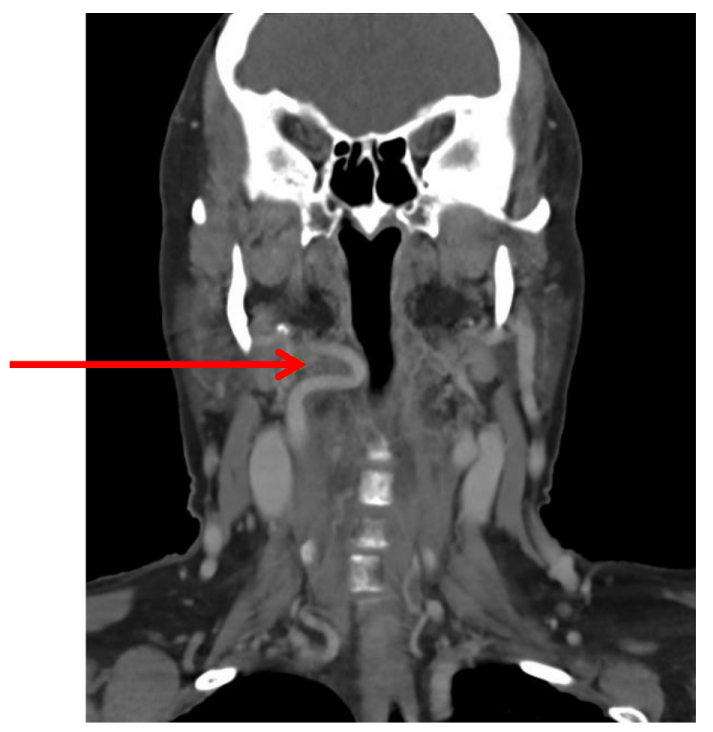

Figure 1 CT scan: coronal section demonstrating tortuous right internal carotid artery (arrow).

Risks of carotid tortuosity should be considered prior to neurosurgery, as detailed by Brachlow et $a l,{ }^{10}$ following the death of a 30 -year-old man who

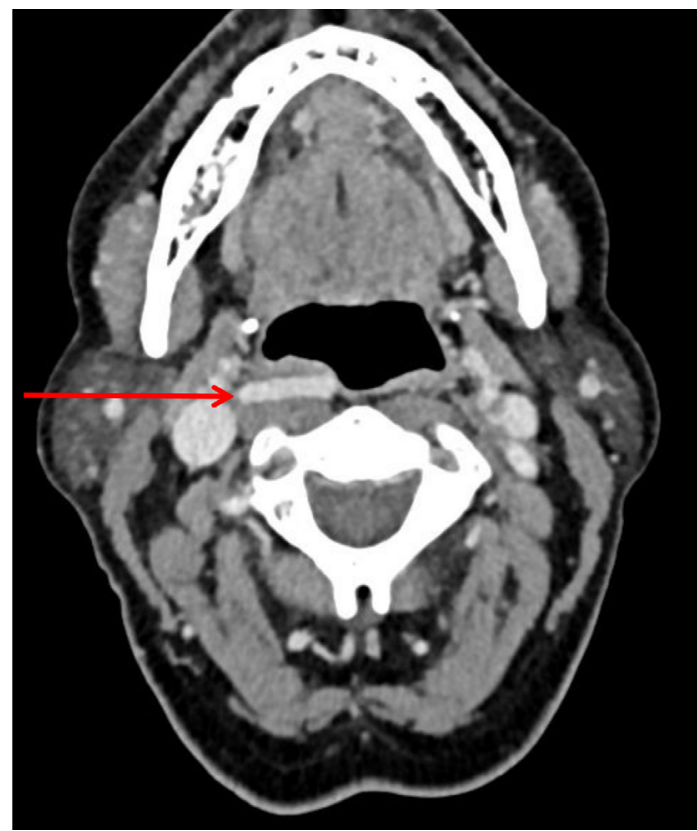

Figure 2 CT scan: axial section demonstrating tortuous right internal carotid artery (arrow). 


\section{Learning points}

- A tortuous cervical internal carotid artery should form part of the differential diagnosis for any pharyngeal mass.

- Presenting symptoms may include hoarseness, abnormal throat sensation, throat pain and dysphagia.

- A pulsatile mass should be investigated thoroughly with CT angiogram prior to any intervention or procedure.

underwent cerebral ischaemia and brain death following rotation of the head for surgical positioning.

Additionally, there are anaesthetic risks to consider. Although rare, intubation can pose iatrogenic harm to the pharynx in patients without tortuous ICA, ${ }^{11} 12$ increasing the potential for massive haemorrhage in cervical tortuous ICA. ${ }^{11}$

The vascular multidisciplinary team concluded this case was a normal variant, which required no further vascular investigation or intervention.

Contributors GW conceived of the study and was the responsible consultant. PGD and EW were involved in patient management and review of the manuscript. EW collated the evidence. MP produced the manuscript.

Funding The authors have not declared a specific grant for this research from any funding agency in the public, commercial or not-for-profit sectors.

Competing interests None declared.

Patient consent for publication Obtained.
Provenance and peer review Not commissioned; externally peer reviewed.

\section{ORCID iDs}

Michelle Pipe http://orcid.org/0000-0003-2326-4466

Emma Watts http://orcid.org/0000-0001-7087-7324

\section{REFERENCES}

1 Paulsen F, Tillmann B, Christofides C, et al. Curving and looping of the internal carotid artery in relation to the pharynx: frequency, embryology and clinical implications. J Anat 2000;197 Pt 3:373-81.

2 Muñoz A, De Vergas J, Crespo J. Imaging and clinical findings in patients with aberrant course of the cervical internal carotid arteries. Open Neuroimag J 2010;4:174-81.

3 Gupta A, Winslet MC. Tortuous common carotid artery as a cause of dysphagia. J R Soc Med 2005;98:275-6.

4 Genc S, Acar B, Genc MG. Tortuous internal carotid artery. I Craniofac Surg 2010;21:2033-4

5 Wærsted S, Dethloff T. [The internal carotid artery as a pulsating protrusion into the pharyngeal wall]. Ugeskr Laeger 2016;178. [Epub ahead of print: 11 Jul 2016].

6 Ceylan S, Salman S, Bora F. Anomaly of the internal carotid artery detected during tonsillectomy. J Craniofac Surg 2010;21:1638-9.

7 Metin M, Avcu M, Soyalic H, et al. A rare cause of objective tinnitus: oropharyngeal tortuous carotid. SciFed Journal of Otolaryngology 2018;1.

8 Bektaş D, Caylan R, Korkmaz O, et al. Acquired and congenital internal carotid artery anomalies in two cases: an important threat for the otolaryngologist. Kulak Burun Bogaz Ihtis Derg 2004;13:35-7.

9 Ziókkowska K, Bachvarov C, Sapundzhiev N, et al. Bilateral tortuous internal carotid arteries - a case report, otorhinolaryngologic and general clinical implications. JofIMAB 2017;23:1657-66.

10 Brachlow J, Schäfer M, Oliveira $\mathrm{H}$, et al. [A fatal intraoperative cerebral ischemia following kinking of the internal carotid artery?]. Anaesthesist 1992;41:361-4.

11 Marcucci C, Thomas P, Sewell DA. Retropharyngeal carotid artery: an important anatomic variation for the anesthesiologist. Anesthesiology 2009;111:454-5.

12 Postma GN, Buenting JE, Jones KR. Oropharyngeal perforation after traumatic intubation. Otolaryngol Head Neck Surg 1995;113:290-2.

Copyright 2020 BMJ Publishing Group. All rights reserved. For permission to reuse any of this content visit

https://www.bmj.com/company/products-services/rights-and-licensing/permissions/

BMJ Case Report Fellows may re-use this article for personal use and teaching without any further permission.

Become a Fellow of BMJ Case Reports today and you can:

- Submit as many cases as you like

- Enjoy fast sympathetic peer review and rapid publication of accepted articles

- Access all the published articles

Re-use any of the published material for personal use and teaching without further permission

Customer Service

If you have any further queries about your subscription, please contact our customer services team on +44 (0) 2071111105 or via email at support@bmj.com.

Visit casereports.bmj.com for more articles like this and to become a Fellow 